Biological and Clinical Sciences Research Journal

ISSN: 2708-2261

www.bcsrj.com

DOI: https://doi.org/10.54112/bcsrj.v2020i1.2

Biol. Clin. Sci. Res. J., Volume, 2020: 2

Review Article

\title{
BEGOMOVIRUSES AND BETASATELLITES ASSOCIATED WITH CLCUD
}

\section{*YAQOOB S, FATIMA N, KHAN S, ALI Q, HAFEEZ MM, MALIK A}

\author{
Institute of Molecular Biology and Biotechnology, University of Lahore, Lahore, Pakistan \\ Corresponding author email: s.yaqoob10@gmail.com
}

(Received $5^{\text {th }}$ January 2020; Accepted $4^{\text {th }}$ April 2020)

\begin{abstract}
Begomoviruses are one of the major types of plant viruses. They are transmitted by whitefly and cause many diseases. The CLCUD is the most damaging disease of cotton. It is the vector of begomoviruses, namely as monpartite or bipartite begomoviruses. Bipartite begomoviruses are consisted of A and B DNA molecuales. Monopatite consist of single genome. It is mainly linked with alphasatellites and betasatellites. Alphasatellites can replicate by using replication protein and not called as true satellites. Betasatellites are called as true satellites as they are linked with alphasatellites. Mainly cause tomato yellow leaf curl disease. Begomoviruses are different from other plant viruses as the basis of RNA genomes. DNA beta satellite is involves in suppressing the expressions of genes in plants. It has a major role in preventing RNA silencing by encoding proteins that binds with DNA and target the nucleus of cell. Affected plants show various symptoms such as leaf curling, enations etc. that cause loss in cotton field by preventing the growth. With the help of PCR, $1.4 \mathrm{~kb}$ fragments of DNA have been amplified from DNA template. For cloning the whole begomoviruses genome, a simple method of cloning has been widely used. Cloning is usually done by using the bacteriophage DNA polymerase. The betasatellites have shown association with CLCuD.
\end{abstract}

Keywords: Begomoviruses, whitefly, betasatellites, alphasatellites, cotton, tomato, leaf curl disease

\section{Introduction}

Cotton is considered as cash crop of Pakistan. Cotton plant is used as raw material in textile industry and has a very soft and hairy natural fiber which grows within boll like structures which carried the seeds of cotton. Major countries which are producing cotton are India, China, Brazil, Pakistan, Australia, Uzbekistan, Turkey and USA. Pakistanis fourth largest cotton producing country with $8,800,1000$ (480lb) cotton bales, contributing $2 \%$ to country GDP and up to $8.2 \%$ value in agriculture added. The total estimated area of Pakistan under cotton cultivation was 2.96 million hectares. Pakistan comprises over number of miles, finishing units, oil expellers and more than 1000 ginneries (Abbas et al., 2013; Abbas et al., 2016b; Puspito et al., 2015). Punjab province is producing $80 \%-85 \%$ of cotton whereas Sindh is producing $15-20 \%$ of cotton. In Punjab cotton growing areas are Southern Punjab which are called 'cotton belt' mainly in the areas of Central Punjab and Sindh. Punjab areas mainly include Sahiwal, Faislabad, Toba Tak Singh and Jhang. Sindh areas include Sukkur, Feroze, Hyderabad, Shahdadpur and Sakrand.

Diseases of cotton
In Pakistan yield of cotton is reducing day by day for the last many years due to low quality seed, poor farming practices, rains at time of sowing, increase in temperature at flowering stage, delay the wheat harvest time, attack of insect pests and one of the most common one is cotton leaf curl disease. Mostly the chewing insects included the American, pink, spotted bollworms and army chew the leaves of cotton plants which are thick and juicy. Sucking types of insects are aphids, jassids, thrips, mealybug and whitefly they feed by sucking the other plants (Abbas et al., 2016a; Puspito et al., 2015; Rehman et al., 2017). Mealybug and whitefly are the two insects which are the major threat for cotton crop in present time. Many other diseases of cotton crop such as bacterial disease known as crown gall, fungal disease are verticillium wilt, root knot (nematode) and viral disease known as anthocyanosis, leaf motile and leaf crumple (Husnain, 2016; Rehman et al., 2017).

\section{Cotton leaf curl disease}

Begomoviruses are major viruses that cause cotton leaf curl disease (Figure 1). This disease is mainly caused by whitefly. It is the major biotic constraint to cotton production. The leaf curling, enations, darkening, vein thickening and swollen veins, young leaves become yellowish, bushy appearance, leathery

[Citation: Yaqoob, S., Fatima, N., Khan, S., Ali, Q., Hafeez, M.M., Malik, A. (2020). Begomoviruses and betasatellites associated with CLCuD. Biol. Clin. Sci. Res. J., 2020: 2. doi: https://doi.org/10.54112/bcsrj.v2020i1.2] 
texture, wilted look of the leaves, margins of the leaves inward and outward and stunning of plants are the symptoms of cotton leaf curl virus disease

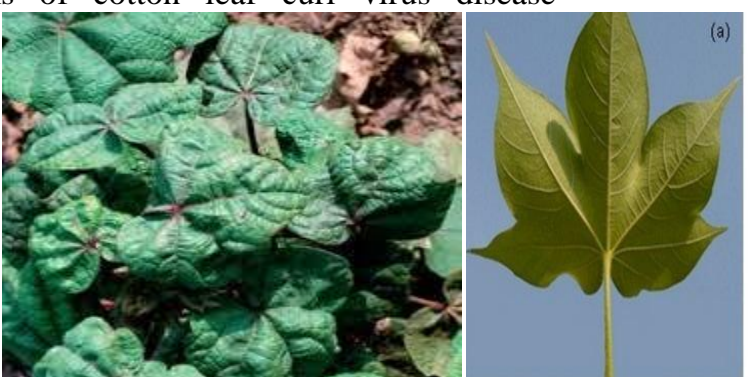

(Airapetian et al., 2004; Dimmock et al., 2008; Rehman et al., 2017).

Fig 1: cotton leaf curl disease in Indian subcontinent (https://alchetron.com/Cotton-leaf-curl-virus)

\section{Viruses}

The virus, also known as poison, word virus is a Latin. Virus is an infectious agent which could move and replicate only within a host cells and has a core of nucleic acid which is either RNA or DNA encapsulated into coat of protein or within a coat of lipid layers. They are inactivated functionally outside the host body and are not able to store free energy or even captured energy. They are not genuine microorganisms usually regarded as pathogens or parasites (Desnues et al., 2008). Dimmock statement about viruses is, "viruses occur universally, most viruses can exist with their hosts. Although viruses are well known for causing disease but can only be detected indirectly" (Dimmock et al., 2008). Martinus Beijerinck in 1898, was discovered the first virus known as Tobacco mosaic virus (TMV). Viruses are of different shapes. Some are helical and some are icosahedra in shape. The size of the viruses varies from 12nm-2000 nm. Miniviruses have the largest genome; the genome size of the miniviruses is $1.2 \mathrm{Mb}$ whereas, ciroviruses and geminiviruses have smallest genome; the genome size of these viruses is 17392819 (Calisher and Van Regenmortel, 2009a). Various diseases are caused by viruses in human, plants and animals. In plants, viruses spread from one host to another by using a vector or carrier. i.e. horizontal gene transfer is considered as important tool to transform gene along with a best source for genetic variations among species (Bernard et al., 2010).

\section{Begomovirus}

Begomoviruses have largest genus from the family Geminiviridae which has above 100 different species. The name of begomovirus has been derived from BGMV or Bean golden mosaic virus (Liu et al., 1997). They affect dicotyledonous plants both in new and old world and are transmitted by Whitefly. Symptoms of begomoviruses infection are vein thickening, leaf curling, enations and yellowing of leaves. They affect crop plants including tomato, cassava, beans, cotton and squash. Due to resistance point of view we study deeply this virus.
Begomoviruses are classified as two groups the monopartite and bipartite based on its genomic size. 2.6- $2.8 \mathrm{~kb}$ size of each genomic component (Briddon and Markham, 2000).

\section{Bipartite begomoviruses}

Genome of bipartite begomoviruses is consisted of DNA A and B both. The DNA A encoded replication which is associated with protein, coat protein, transcriptional activator protein, the replication enhancing protein and encoded protein that has been involved in movement of virus, the RNA suppressor for splicing and determinant for pathogenicity. DNA$\mathrm{B}$ encodes movement protein and nuclear shutter protein (Van Regenmortel, 2007).

\section{Monopartite begomoviruses}

Monopartite begomoviruses have a role as a progenitor molecule. It has a single genome component of DNA A. Monopartite begomoviruses only reported in old world. Have same components like bipartite begomoviruses, contain six ORFs, four are the complementary sense and two are virion sense.

\section{Becurtoviruses}

Becurtoviruses genome consists of three ORFs (V1, $\mathrm{V} 2$, and V3) in the virion-sense strand and two complementary - sense ORFs $(\mathrm{C} 1, \mathrm{C} 2)$. The V1, V2, V3 encode coat protein, movement protein and protein involved in regulating SSDNA. The $\mathrm{C} 1, \mathrm{C} 2$ ORFs have the same position in genome like Mastrevirus. Becurtoviruses have no C3 and C4 ORFs. Rep ORFs contain intron sequence. It has TAAGATTCC mononucleotide sequence at the v-ori. Capulavirus

Replication associated proteins from spliced transcript are encoded by two complementary senses $(\mathrm{C} 1, \mathrm{C} 2)$. Canonical ring circle replication motifs the ATPase motifs Walker A, B, C contained by replication protein of Capulavirus and in amino acid sequences Rep sequence of geminiviruses are present. C3 is embedded in C1 ORF.

\section{Grablovirus}

Other monopartite geminiviruses ranging from 2.7 to $3.0 \mathrm{~kb}$ but the monopartite genome of $3.2 \mathrm{~kb}$ of [Citation: Yaqoob, S., Fatima, N., Khan, S., Ali, Q., Hafeez, M.M., Malik, A. (2020). Begomoviruses and betasatellites associated with CLCuD. Biol. Clin. Sci. Res. J., 2020: 2. doi: https://doi.org/10.54112/bcsrj.v2020i1.2] 
grapevine red blotch virus is larger than other monopartite geminiviruses. The genomic organization of this virus is not similar to that of other geminiviruses. The virion sense and complementary sense ORFs have no homologous in members of the other genera in the family.

\section{Eragroviruses}

Eragroviruses have very rare organization of genome with a TAAGATTCC sequence at virion strand origin of replication and different or unspliced Rep (like Becurtoviruses). Genome of Eragroviruses is similar with others genome by showing unique geminiviruses genera. The C2 ORF is similar with begomovirus, Topocovirus and CurtovirusTrAP/TrAP-like genes because it is a positional analog for all of these. Eurasian mastreviruses is similar with V1 ORF which is mainly encoding the capsid protein of Geminiviruses. The Eragroviruses Rep is mostly related to those of begomoviruses, Curtoviruses, and Topocovirus.

\section{Cotton leaf curl disease history}

\section{Africa}

In 1912, in Nigeria a mycologist first time report the evidence of cotton leaf curl disease in the native cotton species like Gossypiumperuvianum and Gossypiumvitifolium with the leaf curl and vein thickening symptoms. Farquharson was first time used the term 'leaf curl'(Farquharson, 1912). In 1924 this disease was appear again in irregular intervals in time. This disease was reported again from Gezira, Sudan and named as "Stenosis in cotton" in the same year (Lambert, 1924). In 1926, disease samples which were collected from southern Nigeria and herbarium specimens collected from Sudan, was examined by Jones and Mason and called it as a viral disease (Jones and Mason, 1926). Disease appeared in epidemic form in Sudan in 1927-28 and affects half of the cotton crop in Gezira (Kerr and Bailey, 1934). Many Bemisia sp. and infestation of whitefly were found to link with leaf curl symptoms development (Hussain and Al-Jaloud, 1995).

\section{Asia}

In Asia, during 1967 CLCuD was first time reported in Pakistan near the district of Multan (Ryan). Sporadic form of the disease was reported after 20 years. S-12 is a high yielding cotton variety but in 1988, serious infection was observed on S-12 at MozaKhokran near district of Multan. Since that time, in all major cotton growing areas of Pakistan infection was recorded but losses of disease was remained under control for sometimes. S-12 and CIM-70 are two high yielding cotton varieties and have high susceptibility. 'Desi cotton' is totally immune to leaf curl disease but the farmers choose 'American cotton' which is highly susceptible.
Although incidence of the disease was much lower in Sindh as compare to Punjab (Stoilov et al., 1998). In 1992-1997, at high level loss in the economy of Pakistan due to this disease. By using methods like conventional breeding and selection methods resistant varieties were introduced to reduce this disease and then there is increase in economy of Pakistan by overcome this disease (Abdel-Rahman et al., 2002). But with the passage of time the symptoms of the disease were appear to the previous cotton resistant varieties at the district of Burewala and Vehari in 2001 and covered the whole district at the end of 2002 (Briddon, 2003; Mansoor et al., 2003). Strains of the cotton leaf curl virus was confirmed by molecular analysis and grafting (Amiji et al., 2011).Viruses causing leaf curl disease is highly present in the area of Sindh both in central, lower Sindh and cause substantial losses (Amrao et al., 2010).

\section{Satellites associated with monopartite begomoviruses}

Satellites act as sub viral agents known as nucleic acid molecules that depend upon helper virus for their replication. They have no nucleotide sequence which is similar to helper virus genome (Fauquet et al., 2008). Satellite viruses and virus associated satellites have a very clear difference. Virus satellites depend upon helper virus for their purpose. Satellite virus encodes for their encapsulation by themselves. In 1969, first virus satellite was identified (Zhou et al., 2003) due to the leaf curl disease of cotton. It is a monopartite begomoviruses have both associated satellites; Alphasatellite and Betasatellite. Beta satellite is surely associated with this disease and alpha satellite is associated with helper virus (Ciriello et al., 2015; Cordts et al., 2011; Drmanac et al., 2010). Estimate 10 species of cotton leaf curl virus have been reported in Pakistan till now.

\section{Alphasatellite}

They are also known as true satellites because they can replicate themselves by encoding a replication protein. The alphasatellite genome size is almost similar to beta satellite genome. It has a only one Rep gene that is encoded by miniviruses (Claxton et al., 2001; Cordts et al., 2011; Hamilton et al., 1989).

\section{Betasatellite}

It is a monopartite begomoviruses have single genomic component and infectious for the host (Essen et al., 2002). They are circular molecule of ssDNA and depend upon helper virus for replication. Length of the beta satellite is 1350 nt (Amrao et al., 2010; Briddon and Stanley, 2006). Genome of the beta satellite has single ORF in complementary sense, a satellite conserved region and adenine rich region.

[Citation: Yaqoob, S., Fatima, N., Khan, S., Ali, Q., Hafeez, M.M., Malik, A. (2020). Begomoviruses and betasatellites associated with CLCuD. Biol. Clin. Sci. Res. J., 2020: 2. doi: https://doi.org/10.54112/bcsrj.v2020i1.2] 
It has $150-200$ nucleotides in a region known as satellite conserved region.

\section{Begomoviruses and Betasatellites}

In Pakistan and India cotton leaf curl disease causes various loss of production and damage the cotton crop due to this cotton production reduced (Srirajaskanthan and Preedy, 2011). The ssDNA plant viruses are the main cause of CLCuD (Claxton et al., 2001; Mansoor et al., 2003). This family is classified into nine genera. These are Begomoviruses, Grablovirus, Becurtoviruses, Capulavirus, Curtovirus, Mastrevirus, Eragroviruses, Grablovirus and Turncurtovirus (Varma et al., 2011). The largest genus is in Begomovirus family Geminiviridae and it is contains of 320 species (Calisher and Van Regenmortel, 2009b; Zhou et al., 2004). Begomovirusesare transmitted by whitefly (Bisaro et al., 1982). Begomoviruses disease symptoms are leaf curling, small vein thickening, large vein thickening, small leaf like enations under leaf and growth stunting that cause overall loss in crop production. Begomoviruses are classified into 2 main group; Old World and New World (Desnues et al., 2008; Essen et al., 2002; Ndunguru et al., 2005). Begomoviruses are either Bipartite or monopartite on the basis arrangements of genome. DNA satellites molecules are alphasatellites, betasatellites and new one is deltasatellites. Betasatellites are symptoms modulating DNA satellites associated with monopartite begomoviruses in old world. Some betasatellites are associated from malvaceos host from one group and some associated from second group non-malvaceous host. In 1990, the changes that have been occurred in begomoviruses are studied and also study the cotton leaf curl disease in Pakistan. The discovery of cotton leaf curl Multan virus is less extense. A large amount of difference is present in the cotton leaf curl strains of Punjab and Sindh area. Betasatellite is associated with begomoviruses which is reported in a weed and that weed shows yellowish of vein (Hillocks et al., 2002; Jenkin et al., 2003; Saunders et al., 2013). Viral components that cause infection to the host plant were completed after this discovery. The components which are responsible for the production of disease has been reported many times (Kerr and Bailey, 1934; Kitaura et al., 1996; Klug et al., 2008; Saunders et al., 2008). The clones of beta satellites are phenotypically spreaded in the areas of Punjab and Sindh. All betasatellites are recombinant. Therefore, a differentiation in A-rich and SCR which are originated from two provinces (Briddon et al., 2010; Gutierrez et al., 2004; Hull and Davies, 1992).

CLCuMB has more ability of transreplication than other malvaceous and non-malvaceousbetasatellite.
Mutations are found in beta-satellite. Mutations are distributed randomly they are not conserved. Amino acid sequences are requiring for the comparison of beta-satellites. Symptoms of leaf curl virus disease are based on the expression of the protein that is encoded on beta-satellite. In tobacco the amplification of molecules can be determined which is used as a host for the study of plant virus. All type of plant tissues are responded by both biotic and abiotic stresses. In Asia and Africa, begomoviruses are the major problem for the crop plants. In tobacco and Arabidopsis thaliana the method of begomoviruses host interactions are determined. Interactions of geminiviruses with other plants and responses of Arabidopsis are studied. Many research articles are available (Matthews, 1979; Qin et al., 2004; Stoilov et al., 1998). The Nicotana species has also a role in geminiviruses study. The geminiviruses used as plant virus interactions. By using $N$ benthamiana and $\mathrm{N}$-tabacum many strategies against geminiviruses has studied in-vitro. This information will help us to study or determine various differences occur in begomovirus betasatellite complex in association with CLCuD. SiRNA is required for silencing the CLCuMB Band we can increase its level by studying amplicon-based RNAi. There is a need for changing gene construction method in cotton for success and cotton complex begomoviruses is taken under the observation in accordance with the field conditions and it is a big challenge. Many whitefly proteins have been identified recently, which changes the begomovirus transmission may be increase or decrease. Some proteins present in midgut and most of them bind the CP (Turnage et al., 2002; Van Regenmortel, 2007; Varma et al., 2011). Once the begomoviruses are ingested, it emphasizes tissues and further mobilized for the control of virus overflow that may be harmful to insects. A gene is identified recently that gene encode knottin (knot-1) acts as regulator of virus amounts in B.tabaci. During the virus circulation in the insect body this gene help in restraining the amount of TYLCU particles linked with $B$. tabaci. Q biotypes are recently published by the sequences of different genome (Hussain and AlJaloud, 1995; Roberts and Stanley, 1994; Srirajaskanthan and Preedy, 2011). B. tabaci vector help to increase the knowledge of relationships between $B$. tabaci vector intruders and may help to find additional gene that balanced a life between begomoviruses and begomoviruses their Whitefly host.

\section{Future challenge}

1. Use extensive agriculture practices.

2. High yielding varieties are introduced. 
3. Use new host pesticides for increase in the production of whitefly. So whitefly is appear on new host cause increase in the number of this disease and some of them become economically important.

\section{Conclusion}

Viruses that affect our plants like begomoviruses have role in agriculture production. Diseases which are caused by plants viruses are important because they affect our productivity ratio, security of food. Therefore, we have knowledge to control the virus in order to prevent diseases in plants. Recently many experiments are done on plants to prevent virus infection. To control the effect of virus the whole plant is selected for molecular characterization. Universal primers are used for cloning purposes. At the end, the whole sequence was observed to check the similarities and dissimilarities of $\mathrm{CLCuV}$ from other plant viruses

\section{Conflict of interest}

The authors declared the absence of any conflict of interest.

\section{REFRENCES}

Abbas, G., Shahid, M. R., Mahmood, A., and Ali, Q. (2016a). Characterization of plant spacing best fit for economic yield, fiber quality, whitefly and $\mathrm{CLCuV}$ disease management on upland cotton. Nature and Science 14, 12-16.

Abbas, H., Mahmood, A., Ali, Q., Khan, M., Nazeer, W., Aslam, T., and Zahid, W. (2013). Genetic variability, heritability, genetic advance and correlation studies in cotton (Gossypium hirsutum L.). Int. Res. J. Microbiol 4, 156-161.

Abbas, H. G., Mahmood, A., and Ali, Q. (2016b). Zero tillage: a potential technology to improve cotton yield. Genetika 48, 761-776.

Abdel-Rahman, E. M., Younis, M. I., and Nayfeh, A. H. (2002). Characterization of the mechanical behavior of an electrically actuated microbeam. Journal of Micromechanics and Microengineering 12, 759.

Airapetian, A., Akopov, N., Akopov, Z., Amarian, M., Ammosov, V., Andrus, A., Aschenauer, E., Augustyniak, W., Avakian, R., and Avetissian, A. (2004). Evidence for a narrow $\mathrm{S} \mid=1$ baryon state at a mass of $1528 \mathrm{MeV}$ in quasi-real photoproduction. Physics Letters $B$ 585, 213-222.

Amiji, M. M., Hornicek, F., and Duan, Z. (2011). Gene Silencing with siRNA Encapsulated
Nanoparticles to Overcome Tumor Multidrug Resistance. Nanomedicine and Cancer 290.

Amrao, L., Amin, I., Shahid, M. S., Briddon, R. W., and Mansoor, S. (2010). Cotton leaf curl disease in resistant cotton is associated with a single begomovirus that lacks an intact transcriptional activator protein. Virus research 152, 153-163.

Bernard, H.-U., Burk, R. D., Chen, Z., Van Doorslaer, K., Zur Hausen, H., and de Villiers, E.-M. (2010). Classification of papillomaviruses (PVs) based on $189 \mathrm{PV}$ types and proposal of taxonomic amendments. Virology 401, 70-79.

Bisaro, D. M., Hamilton, W., Coutts, R. H., and Buck, K. (1982). Molecular cloning and characterisation of the two DNA components of tomato golden mosaic virus. Nucleic acids research 10, 4913-4922.

Briddon, R., and Stanley, J. (2006). Subviral agents associated with plant single-stranded DNA viruses. Virology 344, 198-210.

Briddon, R. W. (2003). Cotton leaf curl disease, a multicomponent begomovirus complex. Molecular Plant Pathology 4, 427-434.

Briddon, R. W., and Markham, P. (2000). Cotton leaf curl virus disease. Virus research 71, 151-159.

Briddon, R. W., Patil, B. L., Bagewadi, B., Nawazul-Rehman, M. S., and Fauquet, C. M. (2010). Distinct evolutionary histories of the DNA-A and DNA-B components of bipartite begomoviruses. BMC Evolutionary Biology 10, 97.

Calisher, C. H., and Van Regenmortel, M. H. (2009a). Should all other biologists follow the lead of virologists and stop italicizing the names of living organisms? A proposal. Zootaxa 2113, 63-68.

Calisher, C. H., and Van Regenmortel, M. H. (2009b). Should all other biologists follow the lead of virologists and stop italicizing the names of living organisms? A proposal. Zootaxa 2113, 63-68.

Ciriello, G., Gatza, M. L., Beck, A. H., Wilkerson, M. D., Rhie, S. K., Pastore, A., Zhang, H., McLellan, M., Yau, C., and Kandoth, C. (2015). Comprehensive molecular portraits of invasive lobular breast cancer. Cell 163, 506519.

Claxton, A. J., Cramer, J., and Pierce, C. (2001). A systematic review of the associations between dose regimens and medication compliance. Clinical therapeutics 23, 1296-1310.

Cordts, E. B., Christofolini, D. M., dos Santos, A. A., Bianco, B., and Barbosa, C. P. (2011). Genetic

[Citation: Yaqoob, S., Fatima, N., Khan, S., Ali, Q., Hafeez, M.M., Malik, A. (2020). Begomoviruses and betasatellites associated with CLCuD. Biol. Clin. Sci. Res. J., 2020: 2. doi: https://doi.org/10.54112/bcsrj.v2020i1.2] 
aspects of premature ovarian failure: a literature review. Archives of gynecology and obstetrics 283, 635-643.

Desnues, C., Rodriguez-Brito, B., Rayhawk, S., Kelley, S., Tran, T., Haynes, M., Liu, H., Furlan, M., Wegley, L., and Chau, B. (2008). Biodiversity and biogeography of phages in modern stromatolites and thrombolites. Nature 452, 340-343.

Dimmock, D., Zhang, Q., Dionisi-Vici, C., Carrozzo, R., Shieh, J., Tang, L. Y., Truong, C., Schmitt, E., Sifry-Platt, M., and Lucioli, S. (2008). Clinical and molecular features of mitochondrial DNA depletion due to mutations in deoxyguanosine kinase. Human mutation 29, 330-331.

Drmanac, R., Sparks, A. B., Callow, M. J., Halpern, A. L., Burns, N. L., Kermani, B. G., Carnevali, P., Nazarenko, I., Nilsen, G. B., and Yeung, G. (2010). Human genome sequencing using unchained base reads on self-assembling DNA nanoarrays. Science 327, 78-81.

Essen, L. V., Larsson, G., Öberg, K., and Sjödén, P.O. (2002). 'Satisfaction with care': associations with health-related quality of life and psychosocial function among Swedish patients with endocrine gastrointestinal tumours. European journal of cancer care 11, 91-99.

Farquharson, C. (1912). Report of Mycologist. Report of Mycologist.

Fauquet, C., Briddon, R., Brown, J., Moriones, E., Stanley, J., Zerbini, M., and Zhou, X. (2008). Geminivirus strain demarcation and nomenclature. Archives of virology 153, 783821.

Gutierrez, C., Ramirez-Parra, E., Castellano, M. M., Sanz-Burgos, A. P., Luque, A., and Missich, R. (2004). Geminivirus DNA replication and cell cycle interactions. Veterinary microbiology 98, 111-119.

Hamilton, C. M., Aldea, M., Washburn, B., Babitzke, P., and Kushner, S. (1989). New method for generating deletions and gene replacements in Escherichia coli. Journal of bacteriology 171, 4617-4622.

Hillocks, R., Thresh, J., Tomas, J., Botao, M., Macia, R., and Zavier, R. (2002). Cassava brown streak disease in northern Mozambique. International Journal of Pest Management 48, 178-181.

Hull, R., and Davies, J. W. (1992). Approaches to nonconventional control of plant virus diseases. Critical Reviews in Plant Sciences 11, 17-33.
Husnain, T. (2016). Biotechnology: Future Tools for Stable Insect Pest and Weed Control in Cotton. Cotton Genomics and Genetics 7.

Hussain, G., and Al-Jaloud, A. A. (1995). Effect of irrigation and nitrogen on water use efficiency of wheat in Saudi Arabia. Agricultural water management 27, 143-153.

Jenkin, M., Saunders, S., Wagner, V., and Pilling, M. (2003). Protocol for the development of the Master Chemical Mechanism, MCM v3 (Part B): tropospheric degradation of aromatic volatile organic compounds.

Jones, G., and Mason, T. G. (1926). On two obscure diseases of cotton. Annals of Botany 40, 759772.

Kerr, T., and Bailey, I. W. (1934). The Cambium and Its Derivative Tissues: No. X. Structure, Optical Properties and Chemical Composition of the So-called Middle Lamella. Journal of the Arnold Arboretum 15, 327-349.

Kitaura, M., Nakajima, T., Imai, T., Harada, S., Combadiere, C., Tiffany, H. L., Murphy, P. M., and Yoshie, O. (1996). Molecular cloning of human eotaxin, an eosinophil-selective CC chemokine, and identification of a specific eosinophil eotaxin receptor, $\mathrm{CC}$ chemokine receptor 3. Journal of Biological Chemistry 271, 7725-7730.

Klug, S. J., Hukelmann, M., and Blettner, M. (2008). Knowledge about infection with human papillomavirus: a systematic review. Preventive medicine 46, 87-98.

Lambert, M. (1924). A Study of the First Chapter of Genesis. Hebrew Union College Annual 1, 312.

Liu, S., Bedford, I. D., Briddon, R. W., and Markham, P. G. (1997). Efficient whitefly transmission of African cassava mosaic geminivirus requires sequences from both genomic components. Journal of General Virology 78, 1791-1794.

Mansoor, S., Amin, I., Iram, S., Hussain, M., Zafar, Y., Malik, K., and Briddon, R. (2003). Breakdown of resistance in cotton to cotton leaf curl disease in Pakistan. Plant pathology 52, 784-784.

Matthews, S. A. (1979). A simple direction model of electoral competition. Public Choice 34, 141156.

Ndunguru, J., Legg, J. P., Aveling, T., Thompson, G., and Fauquet, C. M. (2005). Molecular biodiversity of cassava begomoviruses in Tanzania: evolution of cassava geminiviruses in Africa and evidence for East Africa being a

[Citation: Yaqoob, S., Fatima, N., Khan, S., Ali, Q., Hafeez, M.M., Malik, A. (2020). Begomoviruses and betasatellites associated with CLCuD. Biol. Clin. Sci. Res. J., 2020: 2. doi: https://doi.org/10.54112/bcsrj.v2020i1.2] 
center of diversity of cassava geminiviruses. Virology journal 2, 21.

Puspito, A. N., Rao, A. Q., Hafeez, M. N., Iqbal, M. S., Bajwa, K. S., Ali, Q., Rashid, B., Abbas, M. A., Latif, A., and Shahid, A. A. (2015). Transformation and Evaluation of Cry1Ac+ Cry2A and GTGene in Gossypium hirsutum L. Frontiers in plant science 6, 943.

Qin, C., Xiao, Q., Li, H., Fang, M., Liu, Y., Chen, X., and Li, Q. (2004). Calorimetric studies of the action of chitosan-N-2-hydroxypropyl trimethyl ammonium chloride on the growth of microorganisms. International journal of biological macromolecules 34, 121-126.

Rehman, I., Aftab, B., Bilal, S. M., Rashid, B., Ali, Q., Umair, M. M., Hassan, S., Azam, A. M., Ahmad, N. I., and Saleem, H. M. (2017). gene expression in response to cotton leaf curl virus infection in Gossypium hirsutum under variable environmental conditions. Genetika 49, 1115-1126.

Roberts, S., and Stanley, J. (1994). Lethal mutations within the conserved stem-loop of African cassava mosaic virus DNA are rapidly corrected by genomic recombination. Journal of General Virology 75, 3203-3209.

Ryan, L. Tag Archives: Solutions.

Saunders, K., Briddon, R. W., and Stanley, J. (2008). Replication promiscuity of DNA- $\beta$ satellites associated with monopartite begomoviruses; deletion mutagenesis of the Ageratum yellow vein virus DNA- $\beta$ satellite localizes sequences involved in replication. Journal of general virology 89, 3165-3172.

Saunders, K., Salim, N., Mali, V. R., Malathi, V. G., Briddon, R., Markham, P. G., and Stanley, J. (2013). Characterisation of Sri Lankan cassava mosaic virus and Indian cassava mosaic virus: evidence for acquisition of a DNA B component by a monopartite begomovirus.

Srirajaskanthan, R., and Preedy, V. R. (2011). Gene Silencing with siRNA Encapsulated Nanoparticles to Overcome Tumor Multidrug Resistance. In "Nanomedicine and Cancer", pp. 298-314. CRC Press.

Stoilov, I., Akarsu, A. N., Alozie, I., Child, A., Barsoum-Homsy, M., Turacli, M. E., Or, M., Lewis, R. A., Ozdemir, N., and Brice, G. (1998). Sequence analysis and homology modeling suggest that primary congenital glaucoma on $2 \mathrm{p} 21$ results from mutations disrupting either the hinge region or the conserved core structures of cytochrome P4501B1. The American Journal of human genetics 62, 573-584.

Turnage, M. A., Muangsan, N., Peele, C. G., and Robertson, D. (2002). Geminivirus-based vectors for gene silencing in Arabidopsis. The Plant Journal 30, 107-114.

Van Regenmortel, M. (2007). Virus species and virus identification: past and current controversies. Infection, Genetics and Evolution 7, 133-144.

Varma, R., Lee, P. P., Goldberg, I., and Kotak, S. (2011). An assessment of the health and economic burdens of glaucoma. American journal of ophthalmology 152, 515-522.

Zhou, H., Tran, P. O. T., Yang, S., Zhang, T., LeRoy, E., Oseid, E., and Robertson, R. P. (2004). Regulation of $\alpha$-cell function by the $\beta$-cell during hypoglycemia in Wistar rats: the "switch-off" hypothesis. Diabetes 53, 14821487.

Zhou, X., Xie, Y., Tao, X., Zhang, Z., Li, Z., and Fauquet, C. M. (2003). Characterization of DNA $\beta$ associated with begomoviruses in China and evidence for co-evolution with their cognate viral DNA-AFN1. Journal of General virology 84, 237-247.

\section{(c) (7) \&}

Open Access This article is licensed under a Creative Commons Attribution 4.0 International License, which permits use, sharing, adaptation, distribution and reproduction in any medium or format, as long as you give appropriate credit to the original author(s) and the source, provide a link to the Creative Commons licence, and indicate if changes were made. The images or other third party material in this article are included in the article's Creative Commons licence, unless indicated otherwise in a credit line to the material. If material is not included in the article's Creative Commons licence and your intended use is not permitted by statutory regulation or exceeds the permitted use, you will need to obtain permission directly from the copyright holder. To view a copy of this licence, visit http://creativecommons.org/licen ses/by/4.0/.

(C) The Author(s) 2021

[Citation: Yaqoob, S., Fatima, N., Khan, S., Ali, Q., Hafeez, M.M., Malik, A. (2020). Begomoviruses and betasatellites associated with CLCuD. Biol. Clin. Sci. Res. J., 2020: 2. doi: https://doi.org/10.54112/bcsrj.v2020i1.2] 